\title{
Updates on the Mechanism and Management of Pterygium: A Brief Review
}

\author{
Fazella Kirara Sakti
}

\section{ABSTRACT}

Pterygium is an ocular surface disease characterized by invasive fibrovascular growth due to pathological proliferation and inflammation on the conjunctival and corneal tissue. Its occurrence has been associated with chronic ultraviolet exposure, thus becoming one of the most common eye problems in tropical regions worldwide. Although pterygium rarely causes severe visual disturbances or blindness, it often becomes a distressing problem because of the high recurrence rate and unsatisfactory cosmetic outcomes, despite receiving removal management. In recent decades, studies regarding molecular mechanisms and management of pterygium have been advanced. This review provides a brief update on the mechanism and management to achieve more optimal and satisfactory pterygium therapeutic approaches.

Keywords: diagnosis, management, pterygium, review.
Submitted : June 26, 2021

Published : July 18, 2021

ISSN: 2593-8339

DOI: $10.24018 /$ ejmed.2021.3.3.949

\section{F. K. Sakti*}

Assistant of Opthalmology Department, Wangaya Public General Hospital, Denpasar, Bali, Indonesia

(e-mail: drfazellakirara@gmail.com)

*Corresponding Author

\section{INTRODUCTION}

Pterygium is the most common triangular fibrovascular proliferative disease characterized by a wing-shaped growth from the bulbous conjunctiva over the ocular surface. This refers to the term "pterygion" or "pterygos" or "pteron", which means a little wing in Greek [1]. The global incidence of pterygium varies from $1.4 \%$ to $33 \%$ and is higher in tropical regions where ultraviolet exposure is more intense with a higher risk of chronic ocular surface dryness [2]. Thus, ultraviolet exposure plays a principal role in the etiopathogenesis of pterygium occurrence. Other risk factors have also been associated with pterygium growth, such as geographical latitude, residence in rural areas, outdoor work, old age, race, sex, chronic irritation, and inflammation process in the ocular surfaces [3].

The growth of pterygium often causes unsatisfactory cosmetic appearance among its sufferers. Although rare, pterygium can also cause visual disturbances by interfering with the tear film stability, obscuring the visual axis, and inducing astigmatism [4]. Surgery is the main principle in pterygium treatment, which aims to improve optical function, cosmetical correction, and reducing complaints. However, the appropriate choice of technique and post-operative adjuvant therapy is still a matter of debate due to the high recurrence rates, which subsequently ended up in dissatisfying clinical outcomes. Currently, various novel treatment modalities for pterygium have been developed, which are believed to improve the clinical benefits among patients. This study emphasized a brief update regarding the diagnosis and management of pterygium to achieve the more optimal and satisfactory therapeutic approaches successfully.

\section{CLINICAL FINDINGS}

The pterygium is characterized by the presence of a triangular growth of fibrovascular tissue, with the tail and body attached to the bulbous conjunctival layer, and the head invading the Bowman's membrane layer so that it extends centrally over the cornea. It is estimated that $90 \%$ of pterygium is located in the nasal conjunctiva because this part receives relatively more solar ultraviolet light from the nasal bone reflection [5]. Thus, pterygium can be classified according to the location of its growth (Fig. 1).
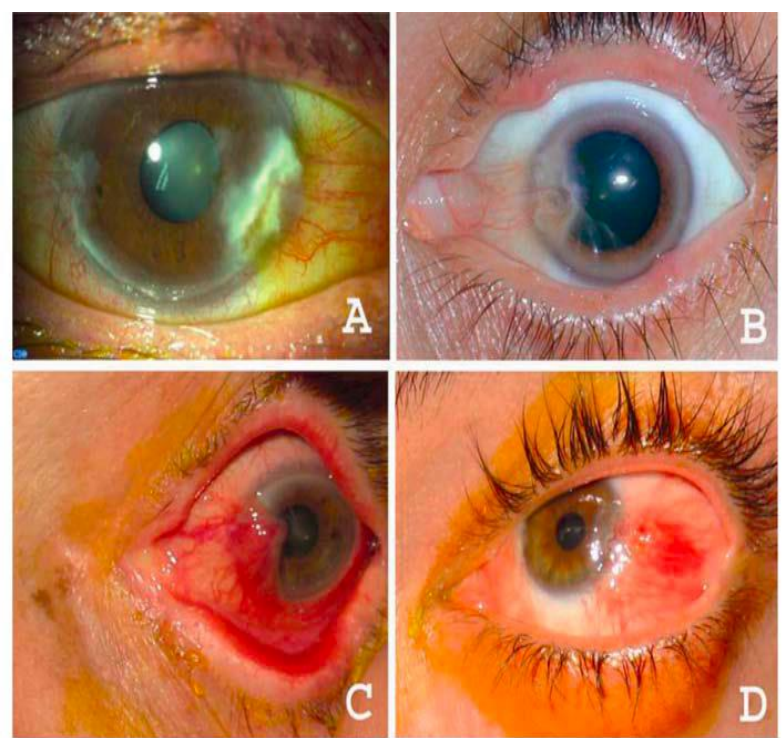

Fig. 1. Clinical findings of pterygium (A) temporal and nasal pterygium (B) quiescent nasal pterygium (C) inflamed nasal pterygium, (D) temporal pterygium [6]. 
Pterygium tissue growth generally follows a horizontal pattern, whereas other tissue growth patterns are usually pseudo-pterygium which can be caused by trauma and inflammation (Fig. 2). Bowman's probe test can be carried out by inserting a probe beneath the lesion to distinguish the two lesions. If the probe can penetrate the lesion, it is indeed a pseudo-pterygium characterized by a lesion that is not firmly attached to the conjunctival layer. Another characteristic feature of pterygium is the presence of iron deposition in the basal layer of cornea epithelium, manifesting as a brownish vertical line at the edge of the tissue growths, known as Stocker's line. This is usually seen at the progressed state of the pterygium due to the presence of lactoferrin in the tear film [7].

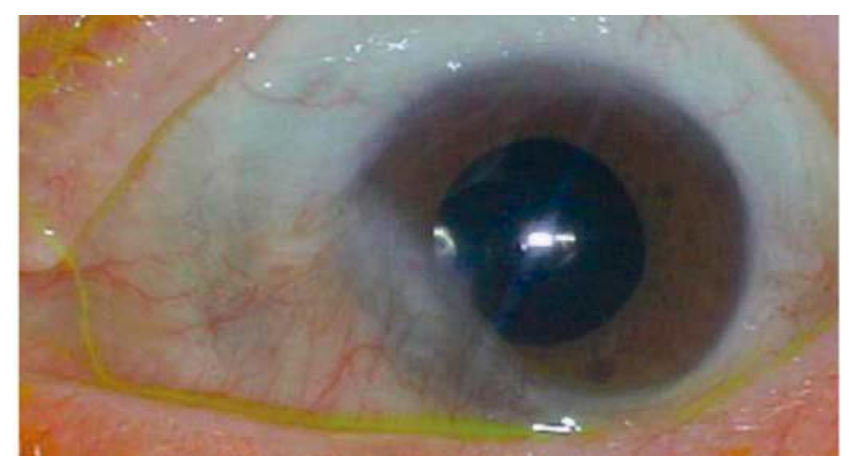

Fig. 2. Pseudo-pterygium at located in the inferior nasal quadrant of the bulbous conjunctiva [6].

\section{MECHANISM OF PTERYGIUM}

Although pterygium has been studied for many years, its exact pathogenesis remains uncertain. The direct pathogenetic role of solar radiation in pterygium development has been reported. Physiologically, the eye has developed an anatomical system that functions as a protector against ultraviolet radiation (UVR), including the eyelids and the structure of the nose and cheeks that allow light to fall right into the refraction medium. However, chronic, and gradual overexposure to UVR will lead to DNA chain damage, oxidative stress, disruption of cell surface receptors, and activation of pathologic intracellular signaling pathways in ocular cells. The effect is closely related to changes in the transcriptional profile of several genes, causing changes in the biological behavior of cells [8]-[10].

Ultraviolet light spans a variety of wavelengths, consisting of UVA (wavelength 315-400 nm), UVB (wavelength 280$315 \mathrm{~nm}$ ), and UVC (wavelength 100-280 nm). The shorter the wavelength, the more energy the UVR produces to exert a mutagenic effect. When the UVR reaches the ocular surface, UV wavelengths below $300 \mathrm{~nm}$ will be absorbed by the cornea. Thus, since the ozone layer has mostly absorbed UVC, the exposure to UVB made a great keynote that contributes to the occurrence of pterygium [11]. The exact mechanism of UVR-induced pterygium began with the genetic destabilization at the limbal basal stem cells and limbal fibroblasts. The role of biomarkers is also associated with the pathological mechanism of pterygium (Fig. 3) [10].

\section{A. Extracellular Matrix Proteins}

Extracellular matrix (ECM) is a structural component of the tissue surrounding cells and plays a role in providing macromolecules and minerals to support cell biochemical processes. An anomalous expression of ECM proteins, including keratin (K8, K10, K14, K16, and AE3), elastin, collagen, and fibrin, correlate with the abnormal proliferation of fibrovascular tissue in pterygium [12]. Specifically, Dake et al. discovered that type II collagen expression was only found in pterygium eyes, but not in normal eyes [13]. However, Girolamo et al. found that the major component of collagen in pterygium eyes was type III collagen [14]. The tropoelastin, which acts to promotes fibroblast migration, is found to be overexpressed in conjunctival tissue with pterygium [15].

\section{B. Matrix Metalloproteinases and Tissue Inhibitors Metalloproteinases}

Matrix metalloproteinases (MMPs) consist of various enzyme components that play a role in ECM degradation. In pterygium, found changes in the expression of substrate components including collagenase (MMP-1), gelatinase (MMP-2, MMP-9), stromelysins (MMP-3), resulting in the invasion of pterygium tissue and dissolution of Bowman's layer, which in turn causes adhesion of lesions on the corneal surface [10]. Meanwhile, tissue inhibitors metalloproteinases (TIMPs) are enzymes that play a role in preventing the activity of MMPs.

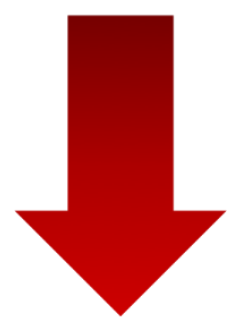

- TGFR- $\beta 1$ and $-\beta 2$

- Claudin-1

- Keratin (K8, K10, K14, K16, AE3), elastin, type II and type III collagen, fibrin

- MMP-1, MMP-2, MMP-3, MMP-9

- IL-1 $\alpha$, IL-1b RA, IL-1b, IL-6, IL-8, IL-17

- VEGF, TGF- $\beta 1$ and $\beta 2$, FDF, IGF, NGF, CTGF, HB-EGF

- Gene p53,p63,p16

- Ki-67, PCNA, cyclin D1

- Survivin, Bcl-2, Bcl-w, mTORC1

- Hsp27, Hsp70, Hsp90, HIF-1 $\alpha$

- ICAM-1, E-cadherin, $\beta$-catenin

Fig. 3. Summary of the molecular biomarkers associated with the pathological mechanism of pterygium. 


\section{Interleukin}

Interleukins (ILs) consist of various components of cytokine proteins that modulate the inflammatory process at the molecular level. Ultraviolet exposure to the ocular surface causes the upregulated expression of IL-6 and IL-8, thereby inducing inflammation that occurs in pterygium [16]. In pterygium, increased expression of IL- $1 \alpha$, IL-1b RA, and IL$1 \mathrm{~b}$ was also found [17]. Jabaran et al. recently determined the role of IL-17 in the pathological mechanism of pterygium [18].

\section{Growth Factors}

Growth factors are molecular substances that are generally secreted to modulate cellular proliferation, differentiation, and migration. Increased expression of several components of growth factors has been shown to play a role in the pathogenesis of pterygium, including vascular endothelial growth factor (VEGF), transforming growth factor-beta (TGF- $\beta$ ), fibroblast growth factor (FGF), insulin-like growth factor (IGF), nervous growth factor (NGF), and connective tissue growth factor (CTGF), and heparin-binding epidermal growth factor (HB-EGF) [10], [19]. Overexpression of TGF$\beta 1$ and TGF- $\beta 2$ were found to be high in pterygium eyes. In contrast, TGF- $\beta$ receptors- 1 and -2 (TGFR- $\beta 1$ and - $\beta 2$ ) were declined in pterygium eyes [20]. VEGF expression was also predominantly found in pterygium eyes, especially in modulating vascular tissue growth in the angiogenesis process [21].

\section{E. Tumor Suppressor Genes}

Tumor suppressor genes are genetic components that generally play a role in regulating the process of apoptosis and preventing the excessive proliferation of cells. This gene dysregulation causes uncontrolled cell growth in pterygium, one of which is p53 gene overexpression [22]. Although infrequent, other genetic components, i.e., p63 and p16, were also found to be altered in pterygium eyes, which were not found in normal eyes [23]. On the other hand, p27 gene expression was decreased in pterygium eyes [24]. Tong stated that with the involvement of $\mathrm{p} 27$, studies on the role of proliferation-related protein cyclin $\mathrm{E}$ are furtherly needed because its inhibition is regulated by the p27 gene [25].

\section{F. Proliferation-related Proteins}

Cell proliferation is regulated by a sequence of coordinated and strictly organized processes so that a controlled cell cycle occurs. Dysregulation of proliferation-related proteins leads to uncontrolled cell proliferation that contributes to pterygium development. The expression of the Ki-67 antigen was found in pterygium eyes and increased with the duration of the disease [22], [26]. A proliferating cell nuclear antigen (PCNA) is a cofactor in DNA polymerase- $\delta$ and is a biomarker that influences abnormal proliferation in pterygium eyes [23]. Other regulators, including cyclin D1 expression, were also found to be increased [24]. However, Süren et al. found no significant difference between pterygium eyes and normal eyes [27].

\section{G. Apoptosis-related Proteins}

Physiologically, the cell cycle is regulated by an apoptotic mechanism that induces cell death, thereby preventing abnormal cell development. Disruption of this mechanism also plays a role in the occurrence of pterygium. The BIRC5 gene regulates the expression of the survivin protein that acts to inhibit caspases, resulting in an antiapoptotic mechanism [28]. In pterygium, hyperproliferation occurs due to enhanced survivin expression, which is also influenced by a decrease in the p63 gene [29]. In addition, inhibition of apoptosis also involves the expression of Bcl-2 and Bcl-w genes. Cell proliferation involving Bcl-2 was influenced by activation of rapamycin complex 1 (mTORC1), which was also found to inhibit the regulation of fibroblast growth factor receptor 3 (FGFR3) [30]. Meanwhile, Bcl-w expression was found to coincide with a decrease in microRNA-122, leading to abnormal apoptotic regulation [31].

\section{H. Heat Shock Proteins}

Heat shock proteins (HSPs) are a group of molecular proteins with cytoprotective roles that protect cells from potentially harmful damage. Expression of HSPs increased in heat shock conditions, as well as in UVR exposure. In pterygium, increased expression of Hsp27 was significantly found in the epithelial, endothelial, and conjunctival vascular smooth muscle cells. In addition, an elevation in the expression of Hsp70 and Hsp90, as well as an alteration of hypoxia-inducible factor-1 $\alpha$ (HIF-1 $\alpha$ ), was also found to induce the mechanism of pterygium [32].

\section{Tight Junction Proteins}

Tight junction proteins consist of a group of proteins that play a role in maintaining cell lining adhesion and ensuring the exchange of protein substances, ions, and other molecules between cells. Tight junctions are mostly composed of the claudins family, where failure to maintain the integrity of claudins is known to contribute to various pathological outcomes. Dogan et al. found that the conjunctiva of pterygium eyes significantly loses the claudin- 1 component, resulting in a breakdown of the intercellular barrier [33].

\section{J. Cell Adhesion Molecules}

Cell adhesion molecules (CAMs) also play a role in the physiological adhesion between cells. In pterygium eyes, upregulation of intercellular adhesion molecule-1 (ICAM-1) induces inflammation in pterygium [34]. Expression of Ecadherin and $\beta$-catenin also causes epithelial and vascular cell adhesion, which further aggravates the pathological process in pterygium [35].

\section{MANAGEMENT}

The method of managing a pterygium is primarily performed by surgical excision. Surgical excision can be combined with graft adherence and the administration of adjuvant therapy, i.e., anti-VEGF agents, to prevent postoperative recurrences. Conservative management is mainly symptomatic and temporary for the early stages of the disease. It involves the use of artificial tears or non-preserved lubricant eye ointment that are helpful to provide comfort and relief of the symptoms [36].

\section{A. Surgical Excision}

The standard of treatment for pterygium currently is the surgical excision; yet there is still no definitive view as to which surgical interventions are most effective [37]. The 
indications for surgical excision are the presence of any disturbance regarding visual function, significant discomfort, cosmetic preferences, and failure of conservative management [36]. There are basic techniques that can be considered in pterygium removal, including bare sclera technique, conjunctival autograft, limbal conjunctival autograft, and the application of amniotic membrane [38].

Technically, pterygium surgery aims to remove the entire fibrovascular tissue, including the head, body, and cap. Surgery can be performed using topical or general anesthesia, depending on the preference of the patient or surgeon. Retrobulbar or peribulbar anesthesia is generally used in patients because it provides relatively better pain control during the surgical procedure [39]. Another alternative is to use subconjunctival anesthesia using lidocaine or proparacaine injection [40]. However, in patients with needle phobia, topical anesthesia with $2 \%$ or $5 \%$ lidocaine gel may be considered [40], [41].

Pterygium removal begins with an incision in the head of the pterygium tissue located at the limbal margin of the cornea. A local anesthetic containing adrenaline is injected, causing ballooning of the surface of the eye to facilitate the incision. The pterygium head is clamped using forceps, then cut using the lamellar corneal blade until it is detached. Excision is continued by removing the remaining pterygium tissue by performing a blunt dissection underneath the pterygium body until it is completely removed from the sclera. Remove the remaining pterygium tissue that has been dissected with forceps, then cut until completely detached, leaving the Tenon's and caruncle tissue underneath as smooth as possible. Ensure that the entire procedure has resulted in a clear corneal bed. If there is bleeding, cautery can be applied to a minimum not to leave further scarring.

Conventional simple excision with bare sclera technique is performed by leaving the remaining area of excised sclera exposed, so that it will be healed with natural reepithelization until it subsequently acts as a barrier for pterygium regrowth. It is rarely done because it has a high recurrence rate, with lesion regrowth tends to be more aggressive [42]. Until now, the conjunctival autograft remains the best choice of surgical technique and is the gold standard that is often used in pterygium surgery. A conjunctival graft is a surgical technique by covering conjunctival defects using a graft, which is generally taken from the bulbous conjunctiva on the supratemporal quadrant. Conjunctival grafts that have been attached can then be fixed with or without sutures using tissue adhesive [43].

Grafts performed with the suture technique often cause post-operative complaints, such as pain and discomfort [42]. The sutureless technique can be a superior alternative to minimize these complications. The sutureless technique has now been developed by applying the use of fibrin glue and autologous blood. Commercial fibrin glue has been widely used because it is considered more convenient and requires a shorter surgical time. However, the availability of commercial fibrin glue is still very limited and quite expensive. It has also been reported to increase the transmission risk of pathogenic infections through blood and high anaphylactic rate among patients. An autologous fibrin glue derived from the patient's blood could be used to overcome these shortcoming issues. It is more cost-effective by not requiring additional special procedures, with a lower risk of allergy and infection because the blood specimens come from the patient. However, this procedure requires a longer time to prepare because it requires special laboratory techniques and equipment, making it difficult to perform in remote areas or patients with low socioeconomic status [42].

Amniotic membrane grafting is another technique that uses the amniotic membrane to cover the exposed sclera after the excision of the pterygium. It can be implemented directly when it is fresh or after cryopreserved. Due to the absence of human leukocyte antigens, the use of an amniotic membrane provides a minimal risk of tissue rejection. Amniotic grafts are thought to promote healing and reduce recurrence rates because of their anti-inflammatory effects, promoting epithelial growth, as well as inducing the suppression of TGF- $\beta$ and fibroblast proliferation. The amniotic membrane is placed over the surface of the sclera, with the base facing up and the avascular stroma facing down the sclera. The use of fibrin glue also plays a role in helping the amniotic membrane to adhere to the episcleral tissue [42].

Other tissue excision techniques are performed using an argon laser and an excimer laser blade [43], [44]. Using these modalities, the main surgical outcome of ensuring a smooth and clear post-excised corneal bed can be easily achieved. However, complications with the laser may occur because of the difficulty of determining the precise separation area at the time of the blunt dissection procedure. The use of pre-surgical ethanol can be a solution to overcome this problem [45]. Ethanol is able to dissolve the junctions between the corneal epithelial cells, making the separation of pterygium tissue easier. This technique can be employed, especially in patients with recurrent pterygium, in which the corneal layer has become thin or in duplex-type pterygium [46].

\section{B. Adjuvant Therapies}

High recurrence rates associated with postsurgical complications continue to be a problem; thus, adjunctive medical management has been incorporated into pterygium's surgical treatment. The adjunctive therapy in pterygium management includes the administration of mitomycin $\mathrm{C}$, anti-VEGF, 5-fluorouracil (5-FU), and loteprednol etabonate [47].

Mitomycin C (MMC) is an antibiotic/antineoplastic substance isolated from Streptomyces caespitosus that has been suggested as adjuvant therapy in pterygium surgery since 1963 [48]. The use of a combination of conjunctival autograft with MMC, regardless of the application dosage or method, revealed significantly lower pterygium recurrence [49], [50]. The use of this regimen can also be given postoperatively, using topical eye drops preparation. Biswas et al. reported that recurrence rates ranged from $4 \%$ to $6 \%$ using $0.02 \%$ and $0.04 \%$ MMC, respectively [51]. Nevertheless, the use of MMC carries a risk of complications of causing chronic keratopathy and toxic keratoconjunctivitis. Therefore, intraoperative use is recommended so that the dosage of this drug can be more easily controlled [47].

Anti-VEGF in adjuvant therapy of pterygium is carried out using bevacizumab preparations. Bevacizumab is a recombinant humanized murine monoclonal immunoglobulin G1 that acts by inhibiting the VEGF-A isoform, thereby 
preventing angiogenesis. This regimen is administered by subconjunctival injection and is expected to reduce pterygium recurrence by reducing neovascularization [52]. Shenasi et al. recommended using subconjunctival bevacizumab injection immediately after pterygium surgery [53]. Another study reported that repeated injections in the first year after surgery might prevent the recurrence rate; however, side effects and high cost for bevacizumab must be considered [54].

5-Fluorouracil is a pyrimidine analog that acts as an antimetabolite inhibiting the DNA synthesis in inducing the proliferation of corneal epithelial cells and conjunctival fibroblast [55]. The dose of $25 \mathrm{mg} / \mathrm{mL}$ of 5-FU can reduce $60 \%$ recurrence rate after bare sclera surgery. Although there is a lack of evidence in the literature to encourage a routinely 5-FU use for surgery, this adjuvant therapy appears to maintain a role in treating recurrent pterygium. However, 5FU has toxicity that still possible even at lower doses. The use of 5-FU is not recommended in patients with a history of corneal diseases [56].

Post-operative inflammation may lead to the recurrence of pterygium. Consequently, different topical steroid regimens have been suggested to control the inflammation process after surgery. It is recommended to use topical prednisolone acetate every two hours for 21 days and then followed four times daily for a further six weeks [58]. The use of corticosteroid regimens such as loteprednol etabonate is also recommended in the management of pterygium. The uniqueness of this regimen lies in its structure, which can penetrate the cell membrane thoroughly and is rapidly converted to inactive metabolites, thereby reducing the risk of side effects of steroid use on the eye, such as increased intraocular pressure and cataract formation. Thus, this regimen can be a potential in future pterygium therapy [47]. Another study demonstrated a reduction in recurrence rate by $50 \%$ by using lubricant eye drops after steroid instillation for a post-surgery period of three months [59].

\section{CONCLUSION}

Pterygium is a unique manifestation of ocular surface disorders characterized by the growth of fibrovascular tissue that resembles a wing-shape lesion. The mechanism of the pterygium is very complex and involves various molecular functions along with biomarker components that are influenced mainly by long-term exposure of ultraviolet. Management of pterygium continues to develop to ensure the success of the operation and minimize postoperative complications and recurrence. Clinicians need to be aware and understand the mechanism of pterygium development to be able to provide an optimal management choice for the patients.

\section{REFERENCES}

[1] L. Liu, J. Wu, J. Geng, Z. Yuan, D. Huang, "Geographical prevalence and risk factors for pterygium: a systematic review and metaanalysis," BMJ Open, vol. 3, no. 11, pp. e003787, Nov 2013.

[2] R. Asokan, R. S. Venkatasubbu, L. Velumuri, V. Lingam, R. George, "Prevalence and associated factors for pterygium and pinguecula in a South Indian population," Ophthalmic Physiol. Opt., vol. 32, no. 1, pp. 39-44, Jan 2012.
[3] F. Rezvan, M. Khabazkhoob, E. Hooshman, A. Yekta, M. Saatchi, H. Hashemi, "Prevalence and risk factors of pterygium: a systematic review and meta-analysis," Surv. Ophthalmol., vol. 63, no. 5, pp. 719 735, Sep-Oct 2018.

[4] R. D. Johnson, V. C. Pai, R. H. Hoft, "Historical approaches to pterygium surgery, including bare sclera and adjunctive beta radiation techniques," in Pterygium: Techniques and Technologies for Surgical Success, J. A. Hovanesian, Ed. Thorofare, NJ: Slack Incorporated, pp. 27-36.

[5] M. Caldwell, L. Hirst, M. A. Woodward, N. Nallasamy, V. Bunya. (March 2021). Pterygium. American Academy of Ophthalmology [Online]. Available: https://eyewiki.aao.org/Pterygium.

[6] E. T. Detorakis, D. A. Spandidos, "Pathogenetic mechanisms and treatment options for ophthalmic pterygium: trends and perspectives (review)," Int. J. Mol. Med., vol. 23, no. 4, pp. 439-447, Apr 2009.

[7] L. W. Hirst, "The treatment of pterygium," Surv. Ophthalmol., vol. 48, no. 2, pp. 145-180, Mar-Apr 2003.

[8] J. P. Fisher. (July 2019). Pterygium. Medscape [Online]. Available: https://emedicine.medscape.com/article/1192527-overview.

[9] H. A. Ginger-Eke, C. E. Ogbonnaya, C. N. Ezisi, "Pterygium: recent trends and perspectives-a review of pathogenesis and current management options," Niger. J. Ophthalmol., vol. 26, no. 2, pp. 89-98, Jan 2018 .

[10] W. P. Zhou, Y. F. Zhu, B. Zhang, W. Y. Qiu, Y. F. Yao, "The role of ultraviolet radiation in the pathogenesis of pterygia (review)," Mol. Med. Rep., vol. 14, no. 1, pp. 3-15, Jul 2016.

[11] J. C. S. Yam, A. K. H. Kwok, "Ultraviolet light and ocular diseases," Int. Ophthalmol., vol. 34, pp. 383-400, Apr 2014.

[12] M. Zhang, Z. Liu, Y. Xie, "The study on the expression of keratin proteins in pterygial epithelium," Yan Ke Xue Bao, vol. 16, no. 1, pp. 48-52, Mar 2000.

[13] Y. Dake, R. Mukae, Y. Soda, M. Kaneko, T. Amemiya, "Immunohistochemical localization of collagen types I, II, III, and IV in pterygium tissues," Acta Histochem., vol. 87, no. 1, pp. 71-74, 1989.

[14] N. D. Girolamo, P. McCluskey, A. Lloyd, M. T. Coroneo, D. Wakefield, "Expression of MMPs and TIMPs in human pterygia and cultured pterygium epithelial cells," Invest. Ophthalmol. Vis. Sci., vol. 41, no. 3, pp. 671-679, Mar 2000.

[15] C. Pérez-Rico, G. Pascual, S. Sotomayor, M. Á. Montes-Mollón, C. Trejo, T. Sasaki, et al., "Tropoelastin and fibulin overexpression in the subepithelial connective tissue of human pterygium," Am. J. Ophthalmol., vol. 151, no. 1, pp. 44-52, Jan 2011.

[16] N. D. Girolamo, R. K. Kumar, M. T. Coroneo, D. Wakefield, "UVBmediated induction of interleukin-6 and -8 in pterygia and cultured human pterygium epithelial cells," Invest. Ophthalmol. Vis. Sci., vol. 43, no. 11, pp. 3430-3437, Nov 2002.

[17] Z. M. Huang, Z. Q. Zhang, Y. F. Li, H. Du, X. M. Yao, "Interleukine1 alpha expression in primary and recurrent pterygium," Chin. J. Pract Ophthalmol., vol. 28, no. 4, pp. 407-409, 2010.

[18] B. Jabarin, A. Solomon, R. Amer, "Interleukin-17 and its correlation with vascular endothelial growth factor expression in ocular surface pathologies: a histologic study," Eur. J. Ophthalmol., vol. 26, no. 4, pp. 283-286, Jun 2016.

[19] N. D. Girolamo, J. Chui, M. T. Coroneo, D. Wakefield D "Pathogenesis of pterygia: role of cytokines, growth factors, and matrix metalloproteinases," Prog. Retin. Eye Res., vol. 23, no. 2, pp. 195-228, Mar 2004.

[20] E. Bianchi, F. Scarinci, C. Grande, R. Plateroti, P. Plateroti, A. M. Plateroti, et al., "Immunohistochemical profile of VEGF, TGF- $\beta$ and PGE2 in human pterygium and normal conjunctiva: experimental study and review of the literature," Int. J. Immunopathol. Pharmacol., vol. 25, no. 3, pp. 607-615, Jul-Sep 2012.

[21] J. Fukuhara, S. Kase, T. Ohashi, R. Ando, Z. Dong, K. Noda, et al., "Expression of vascular endothelial growth factor $\mathrm{C}$ in human pterygium," Histochem. Cell Biol., vol. 139, no. 2, pp. 381-389, Feb 2013.

[22] M. Mood, S. K. Mittal, S. Kishore, A. Singh, N. Gupta, R. Rana, "Expression of p53 and Ki-67 proteins in patients with increasing severity and duration of pterygium," Indian J. Ophthalmol., vol. 69, no. 4, pp. 847-850, Apr 2021.

[23] F. S. Ramalho, C. Maestri, L. N. Z. Ramalho, A. Ribeiro-Silva, E. Romão, "Expression of p63 and p16 in primary and recurrent pterygia," Graefes. Arch. Clin. Exp. Ophthalmol., vol 244, no. 10, pp. 1310-1314, Oct 2006.

[24] S. Kase, S. Takahashi, I. Sato, K. Nakanishi, K. Yoshida, S. Ohno, "Expression of p27(KIP1) and cyclin D1, and cell proliferation in human pterygium," Br. J. Ophthalmol., vol. 91, no. 7, pp. 958-961, Jul 2007. 
[25] L. Tong, "Expression of p27(KIP1) and cyclin D1, and cell proliferation in human pterygium," Br. J. Ophthalmol., vol. 92, no. 1, pp. 157, Jan 2008.

[26] K. Liang, Z. Jiang, B. Ding, P. Cheng, D. Huang, L. Tao, "Expression of cell proliferation and apoptosis biomarkers in pterygia and normal conjunctiva," Mol. Vis., vol. 17, pp. 1687-1693, Jun 2011.

[27] E. Süren, D. Nergiz, B. Bilgin, D. T. Çoban, Z. Akgündüz, C. Sadullahoğlu, et al., "The role of cyclin D1, BCL-2, p53 and Ki-67 in epithelial cells in the etiopathogenesis of pterygium," Indian J. Pathol. Microbiol., vol. 64, no. 2, pp. 238-242, Apr 2021.

[28] C. Maxia, M. T. Perra, P. Demurtas, L. Minerba, D. Murtas, F. Piras, et al., "Expression of survivin protein in pterygium and relationship with oxidative DNA damage," J. Cell Mol. Med., vol. 12, no. 6A, pp. 2372-2380, Dec 2008.

[29] Y. Xu, L. Zhang, D. Zou, Z. Liu, X. Shang, H. Wu, et al., "Differential expression and function of survivin during the progress of pterygium," Invest. Ophthalmol. Vis. Sci., vol. 55, no. 12, pp. 8480-8487, Dec 2014.

[30] Y. Liu, H. Xu, M. An, "mTORC1 regulates apoptosis and cell proliferation in pterygium via targeting autophagy and FGFR3," Sci. Rep., vol. 7, no. 7339, Aug 2017.

[31] Y. H. Cui, H. Y, Li, Z. X. Gao, N. Liang, S. S. Ma, F. J. Meng, et al., "Regulation of apoptosis by miR-122 in pterygium via targeting Bclw," Invest. Ophthalmol. Vis. Sci., vol. 57, no. 8, pp. 3723-3730, Jul 2016.

[32] D. Pagoulatos, N. Pharmakakis, J. Lakoumentas, M. Assimakopoulou, "Hypoxia-inducible factor- $1 \alpha$, von Hippel-Lindau protein, and heat shock protein expression in ophthalmic pterygium and normal conjunctiva," Mol. Vis., vol. 20, pp. 441-457, Mar 2014.

[33] A. S. Dogan, E. Onder, A. T. Arikok, T. Bicer, C. Gurdal, "Claudin-1 expressions decrease in pterygium with respect to normal conjunctiva," Cutan. Ocul. Toxicol., vol. 35, no. 4, pp. 315-318, Dec 2016.

[34] U. Beden, M. Irkec, D. Orphan, M. Orphan, "The roles of Tlymphocyte subpopulations (CD4 and CD8), intercellular adhesion molecule-1 (ICAM-1), HLA-DR receptor, and mast cells in etiopathogenesis of pterygium," Ocul. Immunol. Inflamm., vol. 11, no. 2, pp. 115-122, Jun 2003.

[35] S. Kase, M. Osaki, I. Sato, S. Takanashi, K. Nakanishi, K. Yoshida, et al., "Immunolocalisation of E-cadherin and beta-catenin in human pterygium," Br. J. Ophthalmol., vol. 91, no. 9, pp. 1209-1212, Sep 2007.

[36] A. Alpay, S. H. Uğurbaş, B. Erdoğan, "Comparing techniques for pterygium surgery," Clin. Ophthalmol., vol. 3, pp. 69-74, 2009.

[37] S. I. Van Acker, M. Haagdorens, E. Roelant, J. Rozema, T. Possemiers, V. Van Gerwen, "Pterygium pathology: a prospective case-control study on tear film cytokine levels, vol. 2019, no. 9416262, Nov 2019.

[38] D. Hacioğlu, H. Erdöl, "Developments and current approaches in the treatment of pterygium," Int. Ophthalmol., vol. 37, no. 4, pp. 1073 1081, Aug 2017.

[39] J. Parker. (Januart 2021). Surgical approaches to pterygium. Review of Ophthalmology [Online]. Available: https://www.reviewofophthalmology.com/article/surgical-approachesto-pterygium.

[40] F. Pereira, H. F. Shiroma, M. G. Urias, V. H. Yamada, A. A. S. Lima, A. L. Hofling-Lima, et al., "Pilot study comparing topical anesthetic agents in pterygium surgery: subconjunctival injection versus $2 \%$ lidocaine gel versus $5 \%$ lidocaine gel," Cornea, vol. 37, no. 2, pp. 194 198, Feb 2018.
[41] H. Oksuz, C. Tamer, "Efficacy of lidocaine $2 \%$ gel in pterygium surgery," Acta Ophthalmol. Scand., vol. 83, pp. 206-209, 2005.

[42] V. Damle, "A study to compare conjunctival autografting with sutures and glue free sutureless technique after primary pterygium excision," Int. J. Sci. Study, vol. 5, no. 9, pp. 142-147, 2017.

[43] S. K. Singh, "Pterygium: epidemiology prevention and treatment," Community Eye Health, vol. 30, no. 99, pp. S5-S6, Jan 2017.

[44] K. C. Apaydin, Y. Duranoglu, O. Saka, N. Demirbas, "Argon laser treatment of pterygium," Ann. Ophthalmol., vol. 34, pp. 26-29, Mar 2002.

[45] D. Chen, X. Liu, Q. Long, Z. Wang, Y. Li, "Effects of excimer laser phototherapeutic keratectomy in limbal-conjunctival autograft transplantation for recurrent pterygium: a retrospective case control study," BMC Ophthalmol., vol. 19, no. 238, Nov 2019.

[46] K. H. Chen, W. M. Hsu, "Intraoperative ethanol treatment as an adjuvant therapy of pterygium excision," Int. J. Biomed. Sci., vol. 2, no. 4, pp. 414-421, Dec 2006.

[47] D. Todorovic, T. Sarenac-Voluvic, S. Sreckovic, S. Jovanovic, K. Janicijevic, Z. Todorovic, "Updates on the treatment of pterygium," Serbian J. Exp. Clin. Res., vol. 17, no. 3, pp. 257-261, Sept 2016.

[48] A. L. Young, P. M. Tam, G. Y. Leung, L. L. Cheng, P. T. Lam, D. S. Lam, et al., "Prospective study on the safety and efficacy of combined conjunctival rotational autograft with intraoperative $0.02 \%$ mitomycin C in primary pterygium excision," Cornea, vol. 28, no. 2, pp. 168-169, Feb 2009.

[49] J. Frucht-Pery, F. Raiskup, M. Ilsar, D. Landau, F. Orucov, A. Solomon, "Conjunctival autografting combined with low dose mitomycin C for prevention of primary pterygium recurrence," Am. J. Ophthalmol., vol. 141, no. 6, pp. 1044-1050, Jun 2006.

[50] G. Koranyi, D. Artzen, S. Seregard, E. D. Kopp, "Intraoperative mitomycin $\mathrm{C}$ versus autologous conjunctival autograft in surgery of primary pterygium with four-year follow up," Acta Ophthalmol., vol. 90, no. 3, pp. 266-270, May 2012.

[51] M. C. Biswas, C. Shaw, R. Mandal, "Treatment of pterygium with conjunctival limbal autograft and mitomycin C - a comparative study," J. Indian Med. Assoc., vol. 105, no. 4, pp. 202-204, Apr 2007.

[52] C. C. Teng, N. N. Patel, L. Jacobson, "Effect of subconjunctival bevacizumab on primary pterygium," Cornea, vol. 28, no. 4, pp. 468470, May 2009.

[53] A. Shenasi, F. Mousave, S. Shoa-Ahari, B. Rahimi-Ardabili, R. F. Fouladi, "Subconunctival bevacizumab immediately after excision of primary pterygium: the first clinical trial," Cornea, vol. 30, no. 11, pp. 1219-1222, Nov 2011.

[54] L. R. Stival, A. M. Lago, M. N. Figueiredo, R. H. Bittar, M. L. Machado, J. J. Nassaralla Junior, "Efficacy safety of subconjunctival bevacizumab for recurrent pterygium," Arg. Bras. Oftalmol., vol. 77, no. 1, pp. 4-7, Jun 2013.

[55] C. Akarsu, P. Taner, A. Ergin, "5-Fluorouracil as chemoadjuvant for primary pterygium surgery: preliminary report," Cornea, vol. 22, no. 6, pp. 522-526, Aug 2003.

[56] P. Prabhasawat, N. Tesavibul, K. Leelapatranura, T. Phonjan, "Efficacy of subconjunctival 5-fluorouracil and triamcinolone injection in impending recurrent pterygium," Ophthalmology, vol. 113, no. 7, pp. 1102-1109, Jul 2006.

[57] K. Kampitak, W. Leelewongtawun, S. Leeamornsiri, W. Suphachearaphan, "Role of artificial tears in reducing the recurrence of pterygium after surgery: a prospective randomized controlled trial," Acta Ophthalmol., vol. 95, no. 3, pp. e227-e229, May 2017. 